\title{
Acceptance of Halal Virtual Inspection: Halal Industry Perspective in Malaysia
}

\author{
Nurulhuda Noordin ${ }^{1 *}$, Wan Ahmad Sabirin Ali Azizan², Dewi-Izzwi A.M. ${ }^{3}$, Nor Aziah \\ Daud $^{4}$
}

\author{
${ }^{124}$ Universiti Teknologi MARA Shah Alam, Faculty of Computer \& Mathematical Sciences, 40450, Selangor, \\ Malaysia \\ ${ }^{3}$ Kolej Universiti Poly-Tech MARA, FBASS, 56100, Kuala Lumpur, Malaysia
}

Article History: Received: 11 January 2021; Accepted: 27 February 2021; Published online: 5 April 2021

\begin{abstract}
This paper explores the factors influencing the acceptance of halal virtual inspection. Halal inspection is one of the main critical processes in Halal Certification system. However, due to the problems that occur in Halal Certification system, halal virtual inspection is proposed to overcome the problems. The technology acceptance model (TAM) was adapted as a baseline theory. Survey questionnaires were distributed to 86 respondents who are identified as halal industry players such as producers and consumers of food and beverages sector. The findings of this study reveal that perceived usefulness, perceived ease of use, perceived enjoyment, amount of information, perceived security and trust are the main factors influencing halal virtual inspection acceptance. These factors could be used as a guideline to the halal service providers in order to achieve effective implementation, efficient and trusted halal virtual inspection.
\end{abstract}

Keywords: Halal, Halal Certification, Halal Virtual Inspection, Halal Industry

\section{Introduction}

Halal certification (HC) system is a process of evaluating and confirming that all activities involved in the halal products or services comply with halal requirements, Islamic guidelines and law (shariah) [1-2]. Previous studies [3-4] showed that HC system consists of five main processes such as evaluation of halal application, premise inspection, approval or rejection process, issuance of halal certificate and lastly monitoring process. However, there are several problems that occur in the HC system. A study by [5] emphasized that HC system can be costly, complex and time consuming to be completed. This statement is also supported by [3] which stated that operational inefficiency and governance are the issues in HC system. Therefore, HC system requires better way of implementation to overcome the problems.

One of the main critical processes in $\mathrm{HC}$ system is premise inspection. In Malaysia, premise inspection is a mandatory process in $\mathrm{HC}$ system which must be conducted by the halal service providers. Inspection can be defined as a process of ensuring the related requirements and guidelines have been fulfilled. This process will be conducted by individual or organization [5]. On the other hand, [6] defined inspection as an act of careful and critical checking and evaluation used for many purposes such as aircraft maintenance, baggage screening, food industry, medical sectors and so forth. According to [7], halal inspection is divided into desk inspection and site inspection. Both inspections require the halal auditors to be experts in food technology and Islamic studies to conduct the inspection. Desk inspection is an internal process managed by the halal auditors [8] whereas site inspection is an external process that requires the halal auditors to conduct physical premise evaluation together with other government agencies. The success of the halal certification application relies on the results of the halal inspection. However, the studies by [3-4] highlighted that the lack of staff and understanding of the requirements among the applicants normally lead to the delay in the HC approval. To date, the revolution of technology has improved the human works. In line with that, the halal virtual inspection (HVI) is proposed as an innovation in $\mathrm{HC}$ system which aims to overcome the problems.

This work was supported in part by the UniversitiTeknologi MARA, Shah Alam and KolejUniversiti PolyTech MARA, Kuala Lumpur.

This paper aims to determine the factors influencing the acceptance of halal virtual inspection. The technology acceptance model (TAM) has been adapted in this study. There are six factors tested towards 86 respondents who are the halal industry players. The results of this study is aimed to help the halal service providers to implement effective, efficient and trusted halal virtual inspection. The remainder of this paper is structured as follows; the first section is an introduction, followed by the literature review, the methodology, the findings and discussions, and finally the conclusion. 


\section{Literature Review}

This section discusses topics that are related to the study. The Halal Certification system, the technology and TAM theory are explained in this section.

\subsection{Halal Certification System}

Halal Certification (HC) is the process of evaluating and certifying products or services to ensure that they comply with the halal requirements and Islamic law [1-2]. The HC system provides assurance towards Muslim consumers on the halal product and services. It is a process of examining in detail, documenting and critically evaluating the whole activities and components of services or production chains. The system is used to help consumers and offers guarantee in the consumption of halal foods [9-10]. The HC system consists of five main processes [3]. The first process is to check the application and supporting documents. This is an internal process run by the halal auditors who are experts in food technology and Islamic studies. The second process is to conduct premise inspection. The results of the inspection will help the halal panels to make decision whether the application is approved or rejected. The successful applicants will be issued the halal certificate and allowed to use the halal logo by the certification body. The last process in HC system is the monitoring process. One of the critical HC system processes is halal inspection (HI). HI is important to guarantee that the products or services have fulfilled the halal requirements and Islamic law. A study by [11] illustrated the Halal Ecosystem in detail where the HI is one of the processes in HC system. Figure 1 shows the Halal Ecosystem.

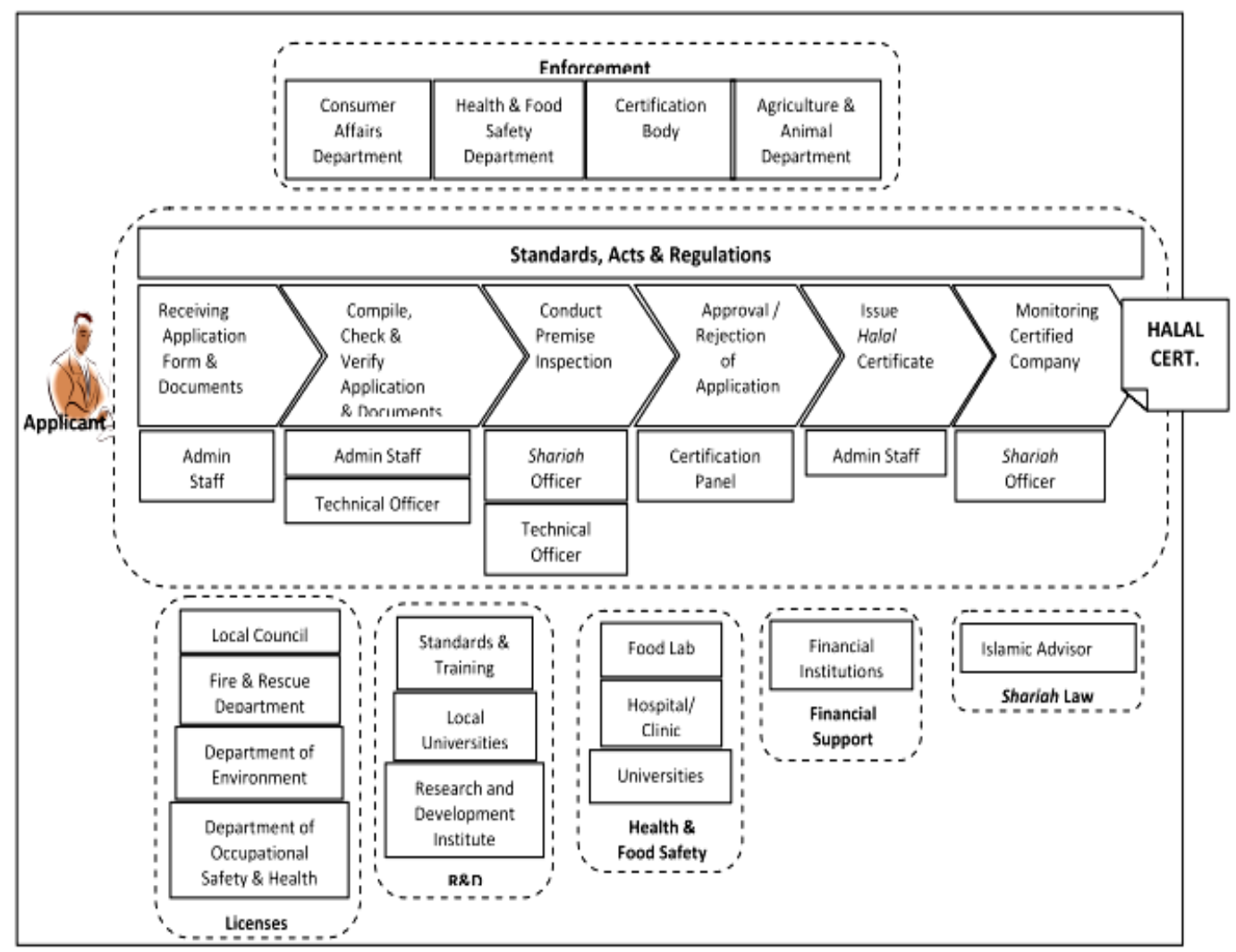

Figure 1Halal Ecosystem [11]

Currently, the information technology used in HC is only on the data management. In Malaysia, the halal industry uses MYeHalal system [12] to apply for the HC. Nowadays, with the advanced technology, virtual technology may be adopted to improve the efficiency and effectiveness of HC system. Various researches on the halal technology have been conducted recently such as a study on halal logo verification using image processing [13] as well as the use of Radio Frequency Identification Technology [14] to support the halal industry in Malaysia. A study by [7] successfully illustrated the halal virtual inspection model and highlighted eleven halal inspection critical points in HC system. Figure 2 shows the Halal Inspection Model [7]. 


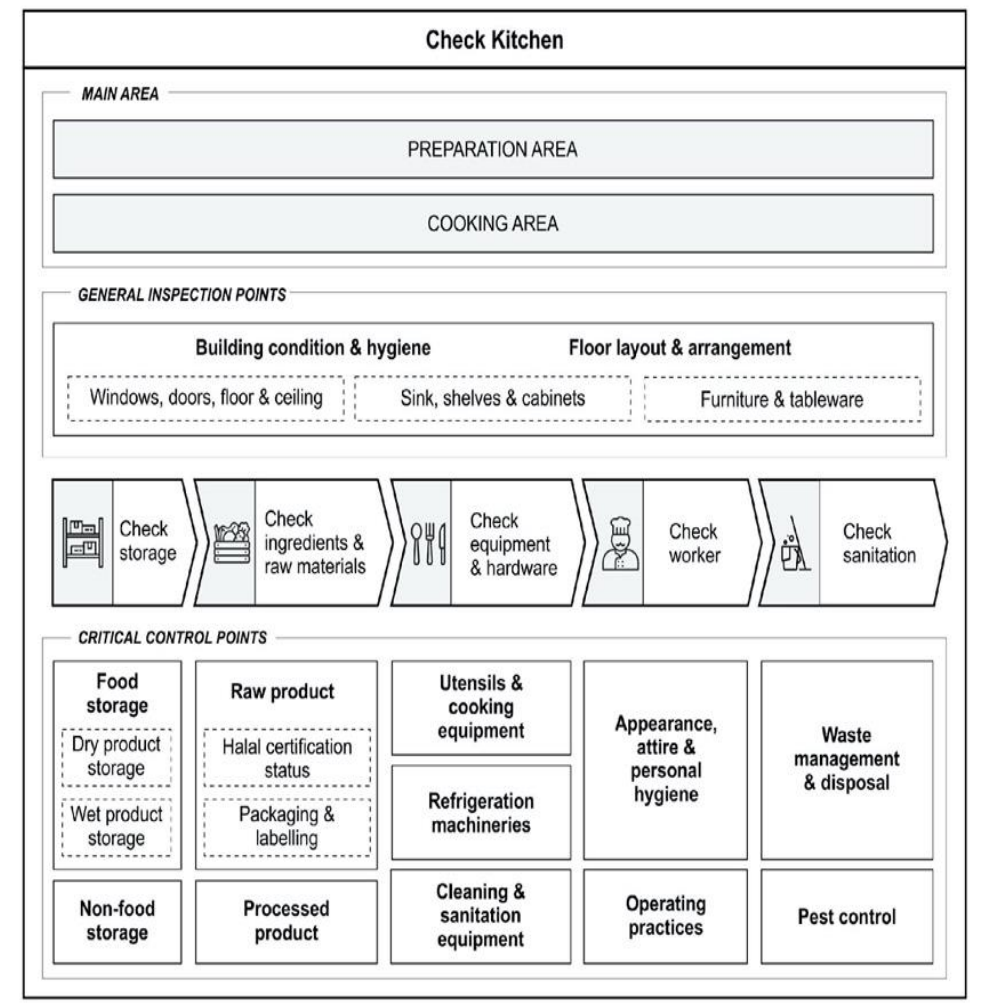

Figure 2HalalInspection Model [7]

\subsection{Virtual Communication Technology}

Revolutionary development of information and communication technology (ICT) has changed humaninteractivity and communication [15]. This technology has been applied in various sectors from data analysis and storage until it is used as communication platform. Virtual communication (VC) technology allows people all over the world to communicate virtually which crosses the boundaries of conventional face-to-face communication. A study by [16] stated that VC technology are cost-effective, and it gives capability to human to interact with each other over the Internet. The human interaction through VC technology can occur synchronously by communicating or delivering information through the Internet or computer devices in real-time (i.e. video conferencing, instant messaging, etc.). Interestingly, not only this interaction can be used as synchronous communication (SC), but it can also occur in asynchronous communication (AC).

VC is related to the Computer Supported Cooperative Work (CSCW) study. The CSCW is a framework on human-computer interaction that gives guidelines on how people can work cooperatively in shared time and space [17]. According to [18-19], CSCW is the process and activity supported by technology to achieve certain goals in which the tools for the interaction can be grouped according to time and space. In this respect, people can collaborate better by giving them a better communication platform, improve monitoring systems and reduce the complexity of activities conducted [18]. A study by [20] explained that the interactivity in cooperative work can occur in several conditions of similar or different time and place as illustrated in Johansen's Time Space Matrix shown in Table 1.

Table 1 Johansen's Time Space Matrix. Adapted from [20].

\begin{tabular}{|c|c|c|}
\hline & Same Time & Different Time \\
\hline Same Place & Face-to-face interaction & Asynchronous int \\
\hline $\begin{array}{l}\text { Different } \\
\text { Place }\end{array}$ & $\begin{array}{l}\text { Synchronous } \\
\text { interaction }\end{array}$ & $\begin{array}{l}\text { Asynchronous } \\
\text { interaction }\end{array}$ \\
\hline
\end{tabular}

The study of halal virtual inspection (HVI) is based on CSCW framework as it offers basic support in how human can interact and work cooperatively with technological supports. Although the implementation HVI may provide better and flexible working environment for the halal service providers, the application of this technology must be complied and handled properly according to Islamic law. 


\subsection{Extension of Technology Acceptance Model (ETAM)}

The Extension of Technology Acceptance Model (ETAM) is an extended model of Technology Acceptance Model (TAM). TAM was introduced by [21] as the powerful and common theory in information technology. Figure 3 shows the Technology Acceptance Model introduced by [21].

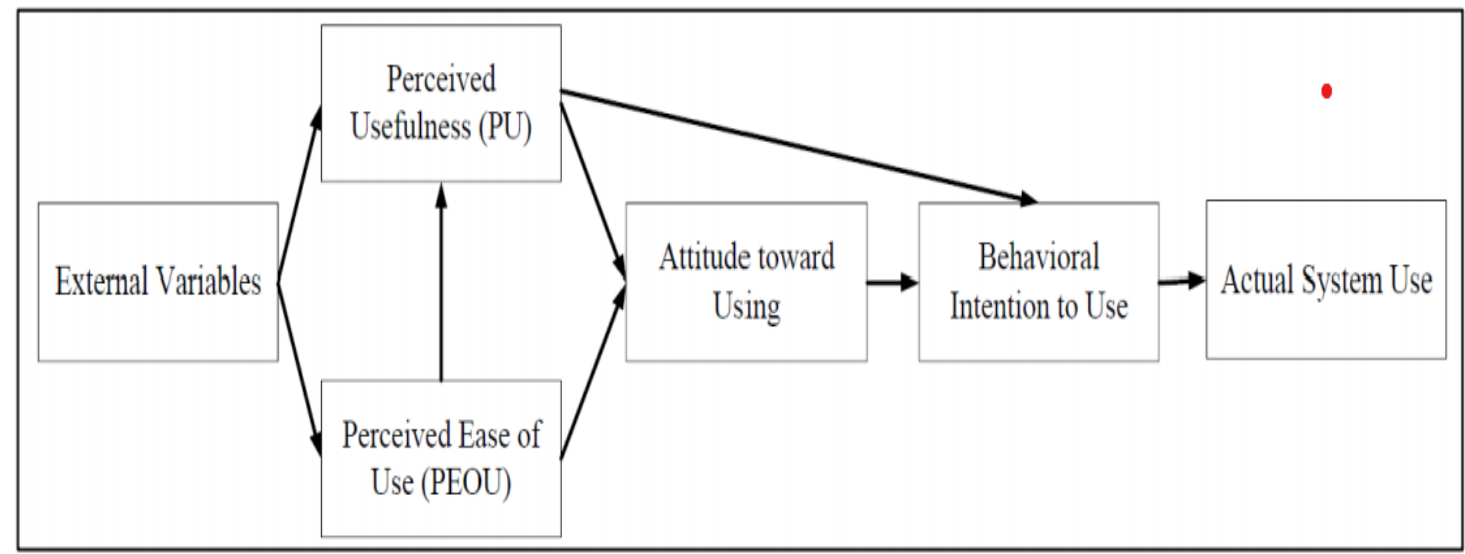

Figure 3Technology Acceptance Model [21]

Many previous studies have proposed extension models by adapting TAM as a baseline theory. ETAM introduces complimentary variables. Table 2 shows several ETAM studies which include new variables based on TAM.

Table 2Extension of Technology Acceptance Model Variables

\begin{tabular}{ll}
\hline Author(s) & Variables used \\
\hline Agarwal \& Pasad [22] & Construct of compatibility with TAM \\
Dishaw \& Strong [23] & Task-technology Fit with TAM \\
Agarwal \& Karahanna & Cognitive absorption, playfulness and self-efficacy in view \\
[24] & of TAM \\
Venkatesh \& Davis [25] & Subjective norms with TAM \\
Chau \& Hu [26] & Peer influence with TAM \\
Chiu et al. [27] & Personal innovativeness with TAM \\
Gefen et al. [28] & Trust with TAM \\
Lin et al. [29] & Technology readiness with TAM \\
Walczuch et al. [30] & Technology readiness with TAM \\
\hline
\end{tabular}

From previous examples of ETAM as summarized in Table 2, it can be seen that the Technology Acceptance Model (TAM) is the suitable theory to be adapted in this study. TAM has become one of the most popular and commonly used models to explain the reasons of user's acceptance towards certain information system [31-32]. It has been applied to various research domains and related applications which has proven its capacity and validity in explaining user behaviour towards adoption of information systems.

\section{Research Methodology}

This section discusses the research model, hypotheses and data collection of this research.

\subsection{Research Model}

The research model of this study is shown in Figure 4. There are six independent variables that are tested in this study. The variables are "Perceived Usefulness", "Perceived Ease of Use", "Perceived Enjoyment", "Amount of Information", "Perceived Security", and "Trust". 


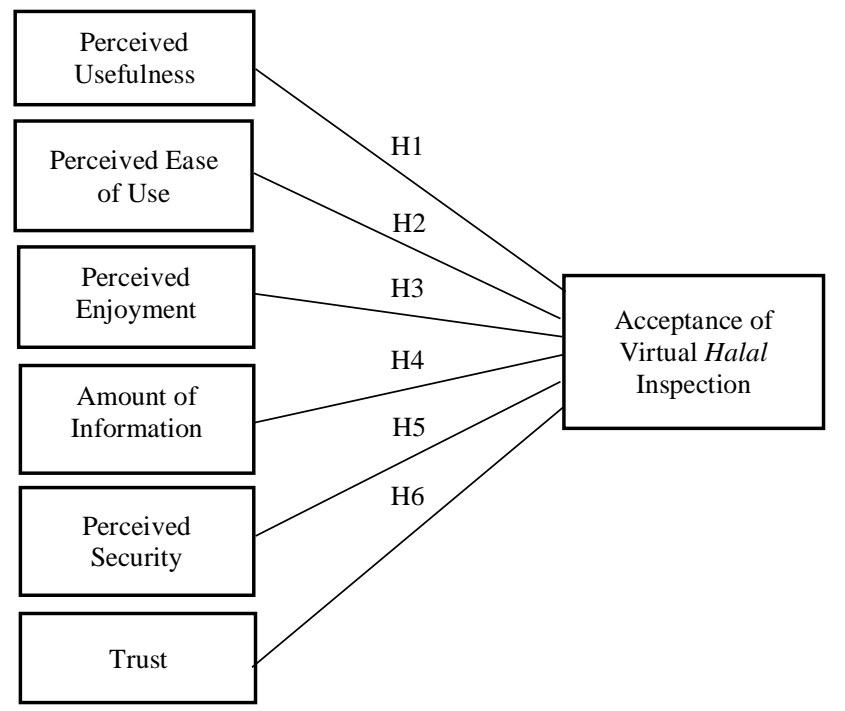

Figure 4Research Model

This study aims to identify acceptance factors of the halal industry towards the implementation of halal virtual inspection. Table 3 summarises the variables' definition of this study.

There are six hypotheses tested in this study in order to determine the relationship between factors that might affect the halal industry's acceptance towards HVI. The hypotheses are:

H1: Perceived Usefulness has a positive effect on consumer preference to use halal virtual inspection

H2: Perceived Ease of Use has a positive effect on consumer preference to use halal virtual inspection

H3: Perceived Enjoyment has a positive effect on consumer preference to use halal virtual inspection

H4: The Amount of Information a consumer has about halal has a positive effect on consumer preference to use halal virtual inspection

H5: Security has a positive effect on consumer preference to use halal virtual inspection

H6: Trust has positive effect on consumer preference to use halal virtual inspection

Table 3 Independent Variable's Definition

\begin{tabular}{ll}
\hline \multicolumn{1}{c}{ Variable } & \multicolumn{1}{c}{ Definition } \\
\hline Perceived Usefulness [21] & $\begin{array}{l}\text { The degree to which consumer believes that using a particular system } \\
\text { would enhance his or her job performance } \\
\text { The degree to which consumer believes that using a particular system } \\
\text { Perceived Ease of Use }\end{array}$ \\
$\begin{array}{l}\text { w1][33] } \\
\text { Perceived Enjoyment [34] } \\
\text { The degree to which consumer perceives a certain technology as } \\
\text { pleasant. This represents an emotional state or an intrinsic motivation } \\
\text { capable of stimulating consumers in continuing such behaviours }\end{array}$ \\
$\begin{array}{l}\text { A quantification of how large a given instance, piece, or pattern of } \\
\text { information is, or how much of a given system's information content } \\
\text { [33][35] }\end{array}$ \\
$\begin{array}{l}\text { (its instance) has a given attribute, such as being known or unknown } \\
\text { Perceived Security [33] }\end{array}$ \\
$\begin{array}{l}\text { The degree to which a consumer believes that using a certain } \\
\text { technology will be secured. It concerns the privacy and perceived risk } \\
\text { in transaction, especially when customer has no experience with the } \\
\text { electronic service } \\
\text { A psychological state involving the intention to accept vulnerability } \\
\text { of positive expectations of another behaviour }\end{array}$ \\
\hline
\end{tabular}

\subsection{Material and Methods}

This study was held in Klang Valley area. The cross-sectional study is adapted based on the reason that the data have been collected over a short period of time with specific respondents and held in Klang Valley area only. The respondents of this study are halal industry players who are the producers or consumers of food and beverages $(\mathrm{F} \& \mathrm{~B})$ sector. For instance, halal consumers from $F \& B$ sector, halal consumers from $F \& B$ manufacturing sector and halal consumers from other sectors such as home bakers and individual food providers. 
Survey questionnaires have been distributed to the targeted respondents in the span of four weeks. The data have been collected from 86 respondents. The survey was constructed based on the six variables, which are "Perceived Usefulness", "Perceived Ease of Use", "Perceived Enjoyment", "Amount of Information", "Perceived Security", and "Trust". The survey questionnaire uses Malay and English language due to the variation of respondents' background. The first part of the survey is the demographic questions which contains 6 questions. The second part consists of 17 questions which focuses on the perception towards HVI. Likert scale ranged from 1 to 5 was used in this study to measure the level of agreement from the respondents. The highest score is 5 and the lowest score is 1.

The data have been analysed using IBM Statistical Package (SPSS). The descriptive statistics are used to analyse the questions and demographic profile of respondents, while Cronbach's alpha is used to measure the reliability of questions.

\section{The Research Findings and Discussion}

This section discusses the findings of the results collected from the survey. Several analyses are discussed in this section including the reliability analysis, descriptive statistics, and correlation analysis.

\subsection{Reliability Analysis}

Reliability analysis refers to the stability and consistency of the instrument measured. The Cronbach's alpha is adapted in this study to measure the reliability and internal consistency. According to [37], the Cronbach's alpha values that range from 0.7 to 1.0 are considered to have adequate reliability whereas those values which approach 0 show poor reliability. Table 4 presents the internal reliability of the variables. In summary, all variables have acceptable Cronbach's alpha values. This eventually shows that all items used for the study are related to each other. The most reliable variable is Perceived Usefulness and the lowest reliable variable is Perceived Security.

Table 4 Reliability Test of the Acceptance Variables

\begin{tabular}{|l|c|c|c|}
\hline \multicolumn{1}{|c|}{ Variable } & No. Of Items & Cronbach's Alpha Value & Conclusion \\
\hline Perceived Usefulness & 5 & 0.905 & Reliable \\
\hline Perceived Ease of Use & 3 & 0.787 & Reliable \\
\hline Perceived Enjoyment & 2 & 0.898 & Reliable \\
\hline Amount of Information & 2 & 0.881 & Reliable \\
\hline Perceived Security & 2 & 0.734 & Reliable \\
\hline Trust & 3 & 0.888 & Reliable \\
\hline
\end{tabular}

\subsection{Descriptive Statistics}

Table 5 shows the demographic background of the respondents. A total of 86 questionnaires were distributed to the respondents. No missing value is recorded. More than half of the respondents of this study are female $(68.6 \%)$, while male respondents accounted for $31.4 \%$ of the sample. Majority of the respondents $(60.5 \%)$ are in the age group of 21-30 years old and the least are aged 18-20 years old (2.3\%). The large proportions of the sample have bachelor's degree where they represent $58.1 \%$ of all samples. Most of the respondents work as Executive (34.8\%). Only 11.6\% respondents are from Food \& Beverage service sector, 5.8\% respondents from Food \& Beverage manufacturing sector and the rest from other sectors $(82.6 \%)$ such as home bakers and individual food providers. The household income for about 91.8\% respondents are below RM10,000 while another $8.2 \%$ of the respondents gain more than RM10,000.

Table 5 Demographic Profile

\begin{tabular}{llcc}
\hline $\begin{array}{c}\text { Personal } \\
\text { Characteristics }\end{array}$ & \multicolumn{1}{c}{ Response Category } & Frequency & $\begin{array}{c}\text { Percentage } \\
(\boldsymbol{\%})\end{array}$ \\
\hline Gender & Male & 27 & 31.4 \\
\multirow{3}{*}{ Age } & Female & 59 & 68.6 \\
& $18-20$ & 2 & 2.3 \\
& $21-30$ & 52 & 60.5 \\
& $31-40$ & 17 & 19.7 \\
Education & $41-50$ & 6 & 7.0 \\
& 51 and above & 9 & 10.5 \\
& SPM & 7 & 8.2 \\
& Diploma & 6 & 7.0 \\
\hline
\end{tabular}




\begin{tabular}{llcc}
\hline \multirow{4}{*}{ Role } & Bachelor & 50 & 58.1 \\
& Postgraduate & 21 & 24.4 \\
& Other & 2 & 2.3 \\
& Management & 9 & 10.5 \\
& Executive & 30 & 34.8 \\
Organization & Support Staff & 9 & 10.5 \\
& Self-employed & 14 & 16.3 \\
& Other & 24 & 27.9 \\
Household Income & Food \& Beverage Service sector & 10 & 11.6 \\
& Food \& Beverage Manufacturing & 5 & 5.8 \\
& Sector & & \\
& Other & 71 & 82.6 \\
& <RM2000 & 21 & 24.4 \\
& RM2001-RM5000 & 35 & 40.7 \\
& RM5001-RM10,000 & 23 & 26.7 \\
& $>$ RM10,000 & 7 & 8.2 \\
\hline
\end{tabular}

\subsection{Acceptance of Halal Virtual Acceptance Among Respondents}

The correlation analysis was produced for all attributes to determine the Pearson correlations with two-tailed significance test as shown in Table 6 . This study adapts the guidelines given by [38]. The correlation coefficient ranges from -1.0 to 1.0 where -1.0 indicates a strong negative association between the variables. Value 1.0 indicates the strong positive association while a correlation of 0 indicates no relationship between two variables.

Table 6 Summary of Bivariate Pearson's rho Correlation Coefficients

\begin{tabular}{lccc}
\hline Relationship & \multicolumn{2}{l}{$\begin{array}{l}\text { Sig. (2-tailed) } \\
\text { Significance 'p' } \\
\text { (rounded) }\end{array}$} & \multicolumn{2}{l}{$\begin{array}{l}\text { Pearson's rho } \\
\text { correlation coefficients } \\
\text { 'r' }\end{array}$} & $\begin{array}{l}\text { Strength of } \\
\text { Relationship }\end{array}$ \\
\hline $\begin{array}{l}\text { Perceived Usefulness } \\
\begin{array}{l}\text { Perceived Ease of } \\
\text { Use }\end{array}\end{array}$ & 0.000 & 0.830 & Strong, positive \\
$\begin{array}{l}\text { Perceived Enjoyment } \\
\text { Amount of }\end{array}$ & 0.000 & 0.818 & Strong, positive \\
$\begin{array}{l}\text { Information } \\
\text { Perceived Security }\end{array}$ & 0.000 & 0.815 & Strong, positive \\
Trust & 0.000 & 0.687 & Strong, positive \\
\hline
\end{tabular}

A study by [38] suggested that $r$ value ranged from 0.50 to 1.0 or -.50 to -1.0 represents large correlation and strong relationship. From Table 6, it shows that all the six variables have strong and positive association towards halal virtual inspection. The most strong and positive relationship is Trust $(r=0.851)$ and less strong and positive is Amount of Information ( $\mathrm{r}=0.687)$.

\section{H6: Trust has positive effect on consumer preference to use halal virtual inspection}

Result from Table 6 indicates that Trust has a significant effect on the consumer preference to use halal virtual inspection ( $\mathrm{p}$-value $<0.05$ ). It can also be concluded that $72.4 \%$ ( $\mathrm{r} 2=0.724$ ) of the variation in halal virtual inspection is explained by the trust. The result is supported by past studies in the same area such as [27] and [28]. The result of this study explains that trust is more needed to rely on when there is a lack of experience based evidence about the system. The trust is also needed when the related actors involved have little knowledge and understanding with each other. The study by [28] stated that trust permits consumers to end up being helpless against the system to guarantee that they pick the expected useful interaction and service. In this study, trust has proven to be a strong influential predictor in acceptance of HVI. It displays the psychological state of halal industry's intention to accept benefits of the decisions of the HVI while at the same time maintaining the consumers' best interest in mind.

H4: The Amount of Information a consumer has about halal has a positive effect on consumer preference to use halal virtual inspection

On the other hand, Amount of Information shows a positive moderate association ( $r=0.687$ ) towards the halal virtual inspection among consumer with p-value equal to 0 . This statement means that $47.2 \%$ (r2=0.472) of the 
variation in halal virtual inspection is explained by the amount of information. The finding is consistent with past studies in the area such as [24] and [26]. In this study, the amount of information has least influence towards acceptance of HVI. The improvement of HVI information and knowledge among the halal industry may increase perceptions of halal industry towards the HVI system.

From the analysis, it is also proven that the halal industry agrees that perceived usefulness $(\mathrm{r}=0.830)$, perceived ease of use $(r=0.818)$, perceived enjoyment $(r=0.815)$ and perceived security $(r=0.752)$ could improve the performance of the HC system. The finding is consistent with past study in the area such as [25]. In this study, the ease of use of the technology and degree of satisfaction of using the system influence the user's intention on the system. A study by [24] supported the finding of perceived security. In this study, the concerns are on the level of confidence in the technology and halal service provider.

\section{Conclusion}

The aim of this study is to gain insights about the factors influencing the HVI acceptance in the halal industry. The research model was constructed based on TAM and tested with surveys among 86 respondents who are in the halal industry. The respondents are from F\&B service sector, F\&B manufacturing sector and interested parties in Klang Valley who volunteered to participate in this study. The results of this study prove that there are six factors that influence the acceptance of HVI which are "Perceived Usefulness", "Perceive Ease of Use", "Perceived Enjoyment", "Amount of Information", "Perceived Security" and "Trust". The most significant factor is Trust and the least significant factor is Amount of Information. The findings are important to assist the halal certification providers and government in order for them to provide an efficient, effective and trusted HVI implementation. With that, it is expected that the problems in HC system could be tackled.

This study however undertakes several limitations. The first limitation is that the study only examined the effects of "Perceived Usefulness", "Perceive Ease of Use", "Perceived Enjoyment", "Amount of Information", "Perceived Security" and "Trust". Thus, the contributions of the study only focus on the variables examined. The future studies are expected to test other factors such as "Government Policy" and "Cost-benefit". The second limitation is that the study was conducted in a short period with small number of sampling from food and beverages industry only. Future works are expected to conduct survey with greater number of sampling from different business context. The third limitation is that the study covered limited geographical area which is only in Klang Valley. The future works are expected to cover Peninsular Malaysia, Sabah and Sarawak. The wider geographical area helps to gain holistic views of the research outcome.

\section{Acknowledgment}

We would like to thank the UniversitiTeknologi MARA, Shah Alam and KolejUniversiti Poly-Tech MARA, Kuala Lumpur for funding and supporting this study.

\section{Conflicts of interest}

The authors have no conflicts of interest to declare.

\section{References}

1. Sulaiman, M.Z.M., Noordin, N., Noor, N.L.M., Ahmad Iqbal Hakim Suhaimi, A.I.H, Isa,W.A.R.W.M., "Halal Virtual Inspection Requirements for Food Premise Inspection Process Towards the Virtualization of Malaysia Halal Certification System", International Conference on Information and Communication Technology for the Muslim World (ICT4M), pp. 12-17, (2018).

2. Alharbi, Y., "Halal Food Certification, Regulations, Standards, Practices, in the Netherlands", MSc. Thesis, Wageningen University and Research Center, Netherlands, (2015).

3. Noordin, N., Noor, N. L.M., Hashim, M., Samicho, Z., "Value Chain of Halal Certification System : A Case of The Malaysia Halal Industry", Eur. Mediterr. Conf. Inf. Syst., 1-14, (2009).

4. Noordin, N., "Efficiency Factors and Ecosystem Framework in Malaysian Halal Food Certification System", Ph.D. Thesis, Universiti Teknologi MARA, (2013).

5. Mohamad, M.N., \& Othman, N., "Audit Pengesahan Halal - Kajian di Jabatan Kemajuan Islam Malaysia”, J. Penyelid. Islam, 22:19-54, (2009).

6. See, J.E., "Visual Inspection: A Review of the Literature", New Mexico, (2012).

7. Sulaiman, M.Z.M., Noordin, N., Noor, N.L.M., Ahmad Iqbal Hakim Suhaimi, A.I.H, Isa,W.A.R.W.M., "Halal Virtual Inspection Critical Control Point", International Journal on Perceptive and Cognitive Computing, 5(2):8796, (2019).

8. Sulaiman, M.Z.M., Noordin, N., Noor, N.L.M., Ahmad Iqbal Hakim Suhaimi, A.I.H, Isa,W.A.R.W.M., "Halal Virtual Inspection Critical Control Point", International Journal on Perceptive and Cognitive Computing, 5(2):8796, (2019).

9. Latif, I. A., Mohamed, Z., Sharifuddin, J., Abdullah, A. M., and Ismail, M. M. 2014. "A Comparative Analysis of Global Halal Certification Requirements," Journal of Food Products Marketing, 20:85-101, (2015). 
10. Abdul Khalek, A., "Young consumers' attitude towards halal food outlets and JAKIM's halal certification in Malaysia", Procedia - Social and Behavioral Sciences 121:26-34, (2014).

11. Noordin, N., Noor, N. L. M., \& Samicho, Z., "Strategic Approach to Halal Certification System: An Ecosystem Perspective", Procedia - Social and Behavioral Sciences, 121:79-95, (2014).

12. Halal Malaysia Official Portal (2020, October 15). System MYeHALAL. Retrieved from http://www.halal.gov.my/v4/index.php?data=bW9kdWxlcy9zeXNfZWhhbGFsOzs7Ow==\&lang=en

13. Kassim, K., Kamal, N.A.M., Diah, N.M., "JAKIM Halal Logo Verification using Image Processing”, International Journal of Advanced Trends in Computer Science and Engineering, 9(1.3 Special), 4:21-26, (2020).

14. Abd Halim, N.H.A., Mansor, H., Hasbullah, N. F., "Halal Kit Identifier using Radio Frequency Identification Technology", International Conference on Vomputer \& Communication Engineering, 126-131, (2016).

15. Mihhailova, G., Õun, K., Türk, K., "Virtual work usage and challenges in different service sector branches", Baltic Journal of Management, 6(3):342-356, (2011).

16. Heller, R. A., "Cost-Benefit Analysis Of Face-to-Face And Virtual Communication: Overcoming the Challenges", CHARS White Papers, Center for Advanced Human Resource Studies, Cornell University ILR School, (2010).

17. Mrázik, M., "Computer Supported Cooperative Work," Comenius University, Bratislava, Slovakia, (2007).

18. Carstensen, P. H., \& Schmidt, K., "Computer supported cooperative work: New challenges to systems design”, K. Itoh (Ed.), Handbook of Human Factors, pp. 619-636 (1999).

19. Stasko, J., "Computer - Supported Cooperative Work (CSCW)," (available at http://www.cc.gatech.edu/ stasko/6750/Talks/24-cscw.pdf), (2007).

20. Penichet, V. M. R., Marin, J. A. I., Gallud, M. D. L., \& Tesoriero, R., "A Classification Method for CSCW Systems", Electron. Notes Theor. Comput. Sci., 168:237-247, (2007).

21. Davis, F. D., "Perceived Usefulness, Perceived Ease of Use, and User Acceptance of Information Technology", MIS Quarterly, 13(3):319-340, (1989).

22. Agarwal, R., \& Prasad, J. "The antecedents and consequents of user perceptions in information technology adoption”, Decision Support Systems, 22(1):15-29, (1998).

23. Dishaw, M. T., \& Strong, D. M. (1999). Extending the technology acceptance model with task-technology fit constructs. Information \& Management, 36(1), 9-21.

24. Agarwal, R., \& Karahanna, E., “Time Flies When You're Having Fun: Cognitive Absorption and Beliefs about Information Technology Usage", MIS Quarterly, 24(4):665, (2000).

25. Venkatesh, V., \& Davis, F. D., "A theoretical extension of the technology acceptance model: Four longitudinal field studies", Management Science, 46(2):86-204, (2000).

26. Chau, P. Y. K., \& Hu, P. J., "Examining a Model of Information Technology Acceptance by Individual Professionals: An Exploratory Study", Journal of Management Information Systems, 18(4):191-229, (2002).

27. Chiu, Y.-B., Lin, C.-P., \& Tang, L.-L., "Gender differs: assessing a model of online purchase intentions in e-tail service", International Journal of Service Industry Management, 16(5):416-435, (2005).

28. Chiu, Y.-B., Lin, C.-P., \& Tang, L.-L., "Gender differs: assessing a model of online purchase intentions in e-tail service", International Journal of Service Industry Management, 16(5):416-435, (2005).

29. Lin, C. H., Shih, H. Y., \& Sher, P. J., "Integrating technology readiness into technology acceptance: The TRAM model", Psychology and Marketing, 24(7):641-657, (2007).

30. Walczuch, R., Lemmink, J., \& Streukens, S., "The effect of service employees' technology readiness on technology acceptance", Information and Management, 44(2):206-215, (2007).

31. Lee, Y., Kozar, K. A., \& Larsen, K. R. T., "The Technology Acceptance Model: Past, Present, and Future", Communications of the Association for Information Systems, 12(50):752-780, (2003).

32. Hui, C., Wenge, R., Xiaoyang, M., Yue, Q., \& Zhang, Xiong, “An Extended Technology Acceptance Model for Mobile Social Gaming Service Popularity Analysis”, Hindawi Mobile Information Systems, 2017:1 -12, (2017).

33. Pikkarainen, T., Pikkarainen, Kari., Karjaluoto, H., Pahmila, S., "Consumer Acceptance of Online Banking: An Extension of the Technology Acceptance Model”, Internet Research, 14(3):224-235, (2004).

34. Ramayah, T., \& Ignatius, J., "Impact of Perceived usefulness, Perceived ease of use and Perceived Enjoyment on Intention to shop online", ICFAI Journal of System Management, 36-51, (2005)

35. Amin, H., Abdul-Rahman, A.R., Ramayah, T., Supinah, R., Mohd-Aris, M., "Determinants of Online Waqf Acceptance: An Empirical Investigation", The Electronic Journal on Information Systems in Developing Countries, 60(8):1-18, (2014).

36. Pavlou, P., "Consumer Acceptance of Electronic Commerce : Integrating Trust and Risk with the Technology Acceptance Model”, International Journal of Electronic Commerce, 7(3):69-103, (2003).

37. Tavakol, M., \& Dennick, R., "Making sense of Cronbach's alpha", International Journal of Medical Education, 2:53-55, (2011).

38. Cohen, J., \& Cohen, P., "Applied multiple regression/correlation for the behavioral sciences", Hillsdale, NJ: Lawrence Earlbaum, (1983). 